\title{
Seasonal diversity and safety evaluation of enterococci population from goat milk in a farm
}

\author{
Patricia Ruiz $^{1}$ - Fátima Pérez-Martín ${ }^{1}$. \\ Susana Seseña ${ }^{1}$ - María Llanos Palop ${ }^{1}$
}

Received: 24 June 2015 / Revised: 23 November 2015 / Accepted: 23 November 2015 /

Published online: 10 December 2015

(C) INRA and Springer-Verlag France 2015

\begin{abstract}
The presence and genetic diversity of enterococci in raw goat milk sampled in a farm during consecutive seasons were evaluated. Representative strains were screened for virulence determinants, susceptibility to antibiotics and the presence of genes involved in biogenic amine production. Counts of enterococci ranged between $2.80 \times 10^{1}$ and $2.50 \times 10^{3}$ cfu. $\mathrm{mL}^{-1}$ with summer samples showing the highest counts and winter samples the lowest. A total of 695 enterococci were isolated and genotyped. One hundred and thirty-three representative isolates from genotypes obtained in randomly amplified polymorphic DNA-polymerase chain reaction (RAPD-PCR) analysis were identified as belonging to Enterococcus faecium (62.9\%), Enterococcus faecalis $(28.2 \%)$ and Enterococcus hirae (8.9\%) species. A higher number of genotypes was observed in the summer and spring samples. The occurrence of antibiotic resistance and virulence genes was strain dependent, although the presence of genes did not always imply resistance, as occurred for vancomycin. All three species showed a high percentage of resistance to tetracycline. Strains from the warmer seasons (spring, summer and autumn) were resistant to a higher number of antibiotics and harboured a higher number of antibiotic resistance and virulence genes. All the strains produced tyramine, while only one E. hirae strain from a spring sample produced putrescine. The feed regime of goats during the warm seasons was the main difference between samples and thus, it could be proposed that the feed is responsible for the differences in the results between seasons.
\end{abstract}

Keywords Enterococci - Goat milk · Seasonal influence - Antibiotic resistance · Virulence $\cdot$ Biogenic amines

María Llanos Palop

MariaLlanos.Palop@uclm.es

Susana Seseña

lasalmur@hotmail.com

1 Department of Analytical Chemistry and Food Technology, Environmental Sciences and Biochemistry Faculty, University of Castilla-La Mancha, Avda. Carlos III, s/n, 45071 Toledo, Spain 


\section{Introduction}

Raw milk is a highly nutritious food presenting a complex microbiota, and it is generally accepted that the lactic acid bacteria (LAB), including those of the Enterococcus (E.) genus, are the dominant population, especially in some types of milk, such as bovine, goat, sheep and buffalo milk (Quigley et al. 2013). However, seasonal variations in the composition of microbial communities in milk due to the combined effects of feeding regime, physiological state and weather have been reported (Callon et al. 2007), which could affect the quality of this product.

Enterococci are a group of bacteria that live as commensals in the gastrointestinal tract of humans and animals, but they can also be isolated from different environmental ecosystems and food (Nishiyama et al. 2015). Their ability to survive in moderately restrictive conditions, such as high-temperature and high-salinity environments and low $\mathrm{pH}$, explains their existence in diverse food products. Among food-associated LAB, enterococci are the most controversial group and important discrepancies exist between studies about their function in foods. While some studies affirm that they have a relevant role in dairy fermentation due to their interesting technological properties (i.e. proteolytic and lipolytic activities, contribution to ripening, development of taste and flavour) (Foulquié Moreno et al. 2006), others associate their presence with negative traits, such as the production of biogenic amines. The presence of aminobiogenic enterococci has been reported in dairy foods, seafood, fermented sausages, dry fermented capers and wine (Jiménez et al. 2013; Nieto-Arribas et al. 2011; Komprda et al. 2010; Pérez-Martín et al. 2014; Pérez-Pulido et al. 2006; Ribeiro et al. 2013; Valenzuela et al. 2010). The aminobiogenic capacity of enterococci is a matter of concern with respect to safety, because of the toxicological problems that ingestion of biogenic amines can cause, even in relatively low amounts.

In addition, in recent decades, enterococci have emerged as human pathogens and their presence has been associated with human diseases, such as bacteriaemia, endocarditis and nosocomial infections, and as a specific threat to public health. Major factors for the pathogenesis of enterococci include the resistance to a wide range of antibiotics and the incidence of numerous virulence determinants, which are both considered as strain-specific properties within the genus (Valenzuela et al. 2009). However, some studies have shown differences in the occurrence of these determinants not only between different Enterococcus species, but also depending on their origin, i.e. from food or from human clinical infections. Eaton and Gasson (2001) reported that E. faecalis strains harboured significantly more virulence determinants than E. faecium strains, and that food strains had fewer virulence determinants than medical strains. Likewise, they demonstrated the horizontal transfer of virulence determinants between strains, a process that is known to take place in the gastrointestinal tract. Consequently, there has been increasing interest in the evaluation of the prevalence of Enterococcus strains harbouring both expressed and silent virulence genes (Kojima et al. 2010), especially in raw substrates, such as milk, that will be used for foods.

Few studies have analysed the stability of microbial communities in milk, included goat milk, over time (Callon et al. 2007; Foschino et al. 2002); however, to our knowledge, the influence of the seasons on the intraspecific diversity and on the safety of the enterococci population existing in goat milk has not yet been studied. 
Therefore, the objectives of this study were the following: (i) to evaluate the presence and genetic diversity of enterococci in raw milk samples from healthy goats in a farm during four consecutive seasons; and (ii) to screen them regarding safety aspects, using both phenotypic and molecular tools, to determine if seasons impact on virulence determinants, the susceptibility to antibiotics and the presence of genes involved in biogenic amine production.

\section{Materials and methods}

\subsection{Source and bacterial isolation}

Milk samples were obtained from an intensive livestock farm located southwest of the city of Toledo, Spain. This farm had a barn with around 1200 Murciano-Granadina breed goats. The animals were in good health and were fed, at a flat rate of 0.8-1.0 kg. $\mathrm{d}^{-1}$, a commercial concentrate consisting of barley, wheat bran, soy hull meal, sunflower seed extract, molasses, calcium carbonate, wheat flour, carob flour, toasted soy extract, corn gluten feed and sodium chloride, with $13.5 \%$ protein, $10,000 \mathrm{IU} . \mathrm{kg}^{-1}$ vitamin A, $2500 \mathrm{IU} . \mathrm{kg}^{-1}$ vitamin D3 and an adequate mineral mixture. Alfalfa $(0.5 \mathrm{~kg})$ and grass silage $(0.5 \mathrm{~kg})$ were also added to this concentrate. No antibiotics were administered. Goats were allocated indoor space with free access to an open yard in warm seasons (spring and summer). In cold seasons (autumn and winter), the access to pasture was around $3 \mathrm{~h} \cdot \mathrm{d}^{-1}$.

A total of 20 milk samples were taken at day 7 after delivery in each season, during the months of May, August and October 2011 and February 2012. During these months, temperatures ranged from $14{ }^{\circ} \mathrm{C}$ to $27^{\circ} \mathrm{C}$ (May), $20^{\circ} \mathrm{C}$ to $35{ }^{\circ} \mathrm{C}$ (August), $10{ }^{\circ} \mathrm{C}$ to $26{ }^{\circ} \mathrm{C}$ (October) and $-2{ }^{\circ} \mathrm{C}$ to $14{ }^{\circ} \mathrm{C}$ (February). Regarding rainfall, the average values were $21 \mathrm{~mm}$ in May, $9 \mathrm{~mm}$ in August, $17 \mathrm{~mm}$ in October and $3 \mathrm{~mm}$ in February.

Before sampling, nipples were cleaned as described by Jiménez et al. (2013). Samples were taken by manual expression using sterile gloves and recovered in a sterile tube. The first drops $(\sim 1 \mathrm{~mL})$ were discarded. Samples were maintained at $4{ }^{\circ} \mathrm{C}$ while being transported to the laboratory, and then analysed immediately.

Samples were diluted in sterile saline solution, plated in duplicate on m-Enterococcus Agar (m-Ent, Difco, Becton Dickinson, Sparks, MD, USA) and incubated aerobically at $37{ }^{\circ} \mathrm{C}$ for $48 \mathrm{~h}$. Counts were expressed as colony forming units (cfu) per millilitre of milk. Colonies were randomly picked and purified by sub-culturing onto the same medium. Pure cultures were Gram stained and tested for catalase and oxidase activities. Only those presumed to belong to the Enterococcus genus were genotyped.

\subsection{Genotyping of isolates by randomly amplified polymorphic DNA-polymerase chain reaction (RAPD-PCR) analysis}

Genomic DNA was obtained from well-developed single colonies on MRSA (Man, Rogosa and Sharpe Agar, Scharlab, Barcelona, Spain) following the procedure described by Pérez-Martín et al. (2014). To genotype isolates, RAPD-PCR analysis 
using the M13 primer (5'-GAGGGTGGCGGTTCT-3'; Integrated DNA Technologies, Inc., Coralville, USA) was performed following the procedure described by Pérez-Martín et al. (2014).

A reproducibility study to determine the minimum percentage of similarity $(r)$ necessary for strain discrimination was also carried out in accordance with these authors.

RAPD-PCR gels were photographed with a KODAK DC290 Zoom Digital Camera (Eastman Kodak Company, Rochester, New York, USA). The patterns were normalised and further processed with the GelCompar version 4.0 analysis software (Applied Maths, Kortrijk, Belgium). Isolates were grouped using the Pearson product-moment correlation coefficient and cluster analysis by UPGMA (Unweighted Pair Group Method with Arithmetic Average).

\subsection{Identification of isolates}

Representative isolates from clusters obtained in the numerical analysis of RAPD-PCR patterns were identified at the species level by species-specific PCR reactions. Primers Efm1 (5'-TGTCAGCAATTGAGAAATAC-3')/Efm2 (5'-CTTCTTTTATTTCTCC TGTA-3'), Efs1 (5'-CTGTAGAAGACCTAATTTCA-3')/Efs2 (5'-CAGCTGTTTT GAAAGCAG-3') and Eh1 (5'-AAACAATCGAAGAACTACTT-3')/Eh2 (5'-TAAA TTCTTCCTTAAATGTTG-3') (Integrated DNA Technologies) for E. faecium, E. faecalis and E. hirae, respectively, and conditions reported by Bensalah et al. (2006), were used. The expected amplicons were 190, 209 and 263 bp, respectively. The reference strains used in this study were E. faecium $410^{\mathrm{T}}$, E. faecalis 184 , and E. hirae $279^{\mathrm{T}}$ from the Spanish Type Culture Collection (CECT).

\subsection{Safety evaluation}

Antibiotic resistance Phenotypic antibiotic resistance to 13 antimicrobials was determined using antibiotic discs (Bio-Rad, Mares-la-Coquette, France). Pharmacological classes and specific antibiotics employed in this study were: $\beta$-lactams (penicillin: $10 \mu \mathrm{g}$ per disc; ampicillin: $10 \mu \mathrm{g}$ per disc), glycopeptides (vancomycin: $30 \mu \mathrm{g}$ per disc; teicoplanin: $30 \mu \mathrm{g}$ per disc), tetracycline $(30 \mu \mathrm{g}$ per disc), aminoglycosides (streptomycin: $10 \mu \mathrm{g}$ per disc; gentamicin: $10 \mu \mathrm{g}$ per disc), chloramphenicol (30 $\mu \mathrm{g}$ per disc), macrolides (erythromycin: $15 \mu \mathrm{g}$ per disc), quinolones (ciprofloxacin: $5 \mu \mathrm{g}$ per disc; norfloxacin: $5 \mu \mathrm{g}$ per disc; levofloxacin: $5 \mu \mathrm{g}$ per disc) and nitrofurans (nitrofurantoin: $300 \mu \mathrm{g}$ per disc).

Cells from overnight cultures in MRS broth (Scharlab) were recovered by centrifugation $\left(10,000 \times g, 5 \mathrm{~min}, 4{ }^{\circ} \mathrm{C}\right)$ and suspended in saline solution until $\mathrm{OD}_{600}=0.5$. Mueller-Hinton agar (Scharlab) plates were seeded with this suspension and 5 minutes later the antibiotic discs were placed onto the surface of the agar.

After incubation at $37^{\circ} \mathrm{C}$ for $24 \mathrm{~h}$, the diameter of inhibition halos around the discs was measured. Strains were classified as sensitive, intermediate or resistant according to the breakpoints recommended by the Clinical and Laboratory Standards Institute (CLSI) (2012). Analyses were carried out in duplicate.

In addition, PCR amplifications of well-known structural genes associated with resistance to tetracycline (tet $\mathrm{L}, \operatorname{tet} \mathrm{M}$, tet $\mathrm{O}$ and $t e t \mathrm{~S})$, vancomycin $(v a n \mathrm{~A}, \operatorname{van} \mathrm{B}$, 
van $\mathrm{C} 1$ and $v a n \mathrm{E})$ and erythromycin $(\operatorname{erm} \mathrm{B}$ and $\operatorname{erm} \mathrm{C})$ were performed using conditions described elsewhere (Comunian et al. 2010; Depardieu et al. 2004; Lemcke and Bülteb 2000; $\mathrm{Ng}$ et al. 2001) and the primers listed in Table 1. Leuconostoc mesenteroides subsp. dextranicum CA2ML1 and E. faecalis NB0E5 from our collection were used as positive controls for tet and van genes and erm genes, respectively.

PCR amplification of virulence factors Multiplex PCR reactions with the primers listed in Table 1 and conditions described by Martín-Platero et al. (2009) were carried out to detect the presence of genes involved in the expression of gelatinase ( $\mathrm{gelE}$ ), hyaluronidase $(h y l)$, the aggregation substance (asal), enterococcal surface protein (esp) and cytolysin (cylA). Strains E. faecalis C24W1, E. avium C8W4 and E. faecium $\mathrm{N} 32 \mathrm{~W} 1$ from our collection were used as positive controls.

Biogenic amine production The potential to produce the biogenic amines tyramine, histamine, putrescine (via ornithine decarboxylase) and cadaverine was assessed using both liquid and solid decarboxylase medium (DM; Bover-Cid and Holzapfel 1999). One percent $(w / v)$ of each precursor amino acid ( ${ }_{L}$-histidine monohydrochloride, $\mathrm{L}_{\mathrm{L}}$-ornithine monohydrochloride, tyrosine disodium salt and $\mathrm{L}^{-}$ lysine monohydrochloride) purchased from Sigma (St. Louis, USA) and 0.005\% $(w / v)$ of pyridoxal-5-phosphate (a cofactor for the decarboxylation reaction) were added to the DM. Each strain was cultured both in $1.5-\mathrm{mL}$ test tubes containing $1 \mathrm{~mL}$ of DM and on plates with and without amino acid (controls). The test tube cultures and plate cultures were incubated for $48 \mathrm{~h}$ at $37{ }^{\circ} \mathrm{C}$ under aerobic and anaerobic conditions (Gas Pack System, Oxoid, Ltd., Basingstoke, Hampshire, UK). All assays were performed in duplicate. Positive reactions were recorded when a purple colour appeared, except for tyrosine plates where a positive reaction was considered when tyrosine precipitates disappeared around the colonies (BoverCid and Holzapfel 1999).

Multiplex PCR reactions for simultaneous detection of the tyrosine decarboxylase $(t d c)$, histidine decarboxylase $(h d c)$ and ornithine decarboxylase $(o d c)$ genes were performed using conditions described by Coton et al. (2010) and the primers listed in Table 1. A PCR internal control corresponding to the 16S rRNA coding gene was included. Strains from our collection (E. faecium Ab16, Oenococcus oeni J34L5 and O. oeni J20L8) were used as $t d c$, $h d c$ and $o d c$ positive controls, respectively.

\section{Results}

\subsection{Bacterial counts}

Counts on m-Enterococcus agar from the 80 milk samples taken at a farm varied with the seasons, and ranged from between $1.00 \times 10^{2}$ and $2.10 \times 10^{2}$ cfu. $\mathrm{mL}^{-1}$ for spring samples; between $1.70 \times 10^{2}$ and $2.50 \times 10^{3}$ cfu. $\mathrm{mL}^{-1}$ for summer samples; between $6.50 \times 10^{1}$ and $1.60 \times 10^{2}$ cfu. $\mathrm{mL}^{-1}$ for autumn samples; and between $2.80 \times 10^{1}$ and $1.14 \times 10^{2}$ cfu. $\mathrm{mL}^{-1}$ for winter samples (data not shown). 
Table 1 Primers used for PCR detection of genes implicated in antibiotic resistance, virulence and biogenic amines

\begin{tabular}{|c|c|c|c|}
\hline Target gene & Primer sequence $\left(5^{\prime}-3^{\prime}\right)$ & Product size (bp) & Reference \\
\hline \multicolumn{4}{|c|}{ Antibiotic resistance } \\
\hline tet $\mathrm{L}$ & $\begin{array}{l}\text { TCGTTAGCGTGCTGTCATTC } \\
\text { GTATCCCACCAATGTAGCCG }\end{array}$ & 267 & (Ng et al. 2001) \\
\hline tet $\mathrm{M}$ & $\begin{array}{l}\text { GTGGACAAAGGTACAACGAG } \\
\text { CGGTAAAGTTCGTCACACAC }\end{array}$ & 406 & (Ng et al. 2001) \\
\hline tet $\mathrm{O}$ & $\begin{array}{l}\text { AACTTAGGCATTCTGGCTCAC } \\
\text { TCCCACTGTTCCATATCGTCA }\end{array}$ & 515 & (Ng et al. 2001) \\
\hline tet $\mathrm{S}$ & $\begin{array}{l}\text { CATAGACAAGCCGTTGACC } \\
\text { ATGTTTTTGGAACGCCAGAG }\end{array}$ & 667 & (Ng et al. 2001) \\
\hline $\operatorname{van} \mathrm{A}$ & $\begin{array}{l}\text { TCTGCAATAGAGATAGCCGC } \\
\text { GGAGTAGCTATCCCAGCATT }\end{array}$ & 377 & (Lemcke and Bülteb 2000) \\
\hline $\operatorname{van} \mathrm{B}$ & $\begin{array}{l}\text { GCTCCGCAGCCTGCATGGACA } \\
\text { ACGATGCCGCCATCCTCCTGC }\end{array}$ & 529 & (Lemcke and Bülteb 2000) \\
\hline $\operatorname{van} \mathrm{C} 1$ & $\begin{array}{l}\text { GAAAGACAACAGGAAGACCGC } \\
\text { TCGCATCACAAGCACCAATC }\end{array}$ & 796 & (Lemcke and Bülteb 2000) \\
\hline $\operatorname{van} \mathrm{E}$ & $\begin{array}{l}\text { TGTGGTATCGGAGCTGCAG } \\
\text { ATAGTTTAGCTGGTAAC }\end{array}$ & 430 & (Depardieu et al. 2004) \\
\hline ermB & $\begin{array}{l}\text { CATTTAACGACGAAACTGGC } \\
\text { GGAACATCTGTGGTATGGCG }\end{array}$ & 425 & (Comunian et al. 2010) \\
\hline erm $\mathrm{C}$ & $\begin{array}{l}\text { ATCTTTGAAATCGGCTCAGG } \\
\text { CAAACCCGTATTCCACGATT }\end{array}$ & 295 & (Comunian et al. 2010) \\
\hline \multicolumn{4}{|c|}{ Virulence factors } \\
\hline gelE & $\begin{array}{l}\text { TATGACAATGCTTTTTGGGAT } \\
\text { AGATGCACCCGAAATAATATA }\end{array}$ & 213 & (Vankerckhoven et al. 2004) \\
\hline$h y l$ & $\begin{array}{l}\text { ACAGAAGAGCTGCAGGAAATG } \\
\text { GACTGACGTCCAAGTTTCCAA }\end{array}$ & 276 & (Vankerckhoven et al. 2004) \\
\hline asal & $\begin{array}{l}\text { GCACGCTATTACGAACTATGA } \\
\text { TAAGAAAGAACATCACCACGA }\end{array}$ & 375 & (Vankerckhoven et al. 2004) \\
\hline esp & $\begin{array}{l}\text { AGATTTCATCTTTGATTCTTGG } \\
\text { AATTGATTCTTTAGCATCTGG }\end{array}$ & 510 & (Vankerckhoven et al. 2004) \\
\hline cylA & $\begin{array}{l}\text { ACTCGGGGATTGATAGGC } \\
\text { GCTGCTAAAGCTGCGCTT }\end{array}$ & 688 & (Vankerckhoven et al. 2004) \\
\hline \multicolumn{4}{|c|}{ Biogenic amines } \\
\hline$t d c$ & $\begin{array}{l}\text { ACATAGTCAACCATRTTGAA } \\
\text { CAAATGGAAGAAGAAGTAGG }\end{array}$ & 1133 & (Coton et al. 2004) \\
\hline$h d c$ & $\begin{array}{l}\text { GATGGTATTGTTTCKTATGA } \\
\text { CCAAACACCAGCATCTTC }\end{array}$ & 435 & (Coton and Coton 2005) \\
\hline$o d c$ & $\begin{array}{l}\text { NCAYAARCAACAAGYNGG } \\
\text { GRTANGGNTNNGCACCTTC }\end{array}$ & 900 & (Coton et al. 2010) \\
\hline $16 \mathrm{~S}$ rRNA & $\begin{array}{l}\text { AGAGTTTGATCCTGGCTCAG } \\
\text { AAGGAGGTGATCCAGCCGCA }\end{array}$ & 1537 & (Edwards et al. 1989) \\
\hline
\end{tabular}


From countable plates, a total number of 800 isolates was obtained, of which 695 were Gram-positive cocci and catalase- and oxidase-negative. Therefore, they were presumptively assigned to the Enterococcus genus and genetically characterised.

\subsection{Genotyping and identification of isolates}

RAPD-PCR analysis of the 695 isolates using the M13 primer discriminated 133 different genotypes (Fig. 1), which were defined at a minimum similarity level of $86 \%$, the value determined in the reproducibility study (data not shown). Eighty-nine clusters comprised two or more isolates, while the remaining clusters comprised only one isolate.

Species-specific PCR reactions using primers Efm1/Efm2, Efs1/Efs2 and Eh1/Eh2 of one isolate that was representative of each RAPD-PCR cluster identified $62.9 \%$ of them as belonging to E. faecium, $28.2 \%$ to E. faecalis and $8.9 \%$ to E. hirae species (Fig. 1). All these species were present in samples from each season (Fig. 2). However, while E. faecium was the predominant species in the spring samples, E. faecalis was predominant in winter and $E$. hirae in summer and autumn samples. The occurrence of $E$. faecalis was higher in cold seasons (autumn and winter), while the occurrence of E. faecium was higher in warm seasons (spring and summer).

Assignment of genotypes (Fig. 1) to species showed that 68 major clusters belonged to E. faecium isolates, 57 to E. hirae isolates, and eight to E. faecalis isolates. The greatest genetic diversity - measured as the ratio of the number of genotypes to the number of isolates-corresponded to E. hirae species with 196 isolates that were clustered in 57 genotypes, followed by E. faecium species, with 437 isolates clustered in 68 major clusters, and E. faecalis species, with 62 isolates grouped in eight different genotypes.

It is important to highlight that 120 of the 133 clusters grouped isolates from samples of one season and only 13 of them grouped isolates from samples of different seasons, i.e. clusters 74 and 80 clustered E. faecium isolates from spring and summer samples; clusters 5, 14 and 85 grouped $E$. faecalis isolates from samples of two or three seasons; and clusters 10, 57, 60, 63, 70, 100, 107 and 131 grouped $E$. hirae isolates, also from two or three seasons.

The same 133 isolates identified by species specific PCR reactions were submitted to safety evaluation. The isolates were from samples of all seasons (46 from spring, 71 from summer, 14 from autumn and two from winter samples) and belonged to E. faecium species (68), E. hirae species (57) and E. faecalis species (8).

\subsection{Antibiotic resistance}

Table 2 shows the results of the phenotypic antibiotic resistance assay. All the strains were susceptible to gentamicin and levofloxacin (data not shown) and, for the remaining antibiotics, differences were observed between both species and seasons. Strains from spring and summer samples were resistant to a higher number of antibiotics: 63, 28,26 and $48 \%$ of isolates were resistant to streptomycin, tetracycline, ciprofloxacin or norfloxacin, respectively. Much lower percentages of isolates (2 to 7\%) were resistant to $\beta$-lactams, vancomycin or chloramphenicol. All isolates were susceptible to teicoplanin and nitrofurantoin. For the autumn strains, the values for streptomycin 


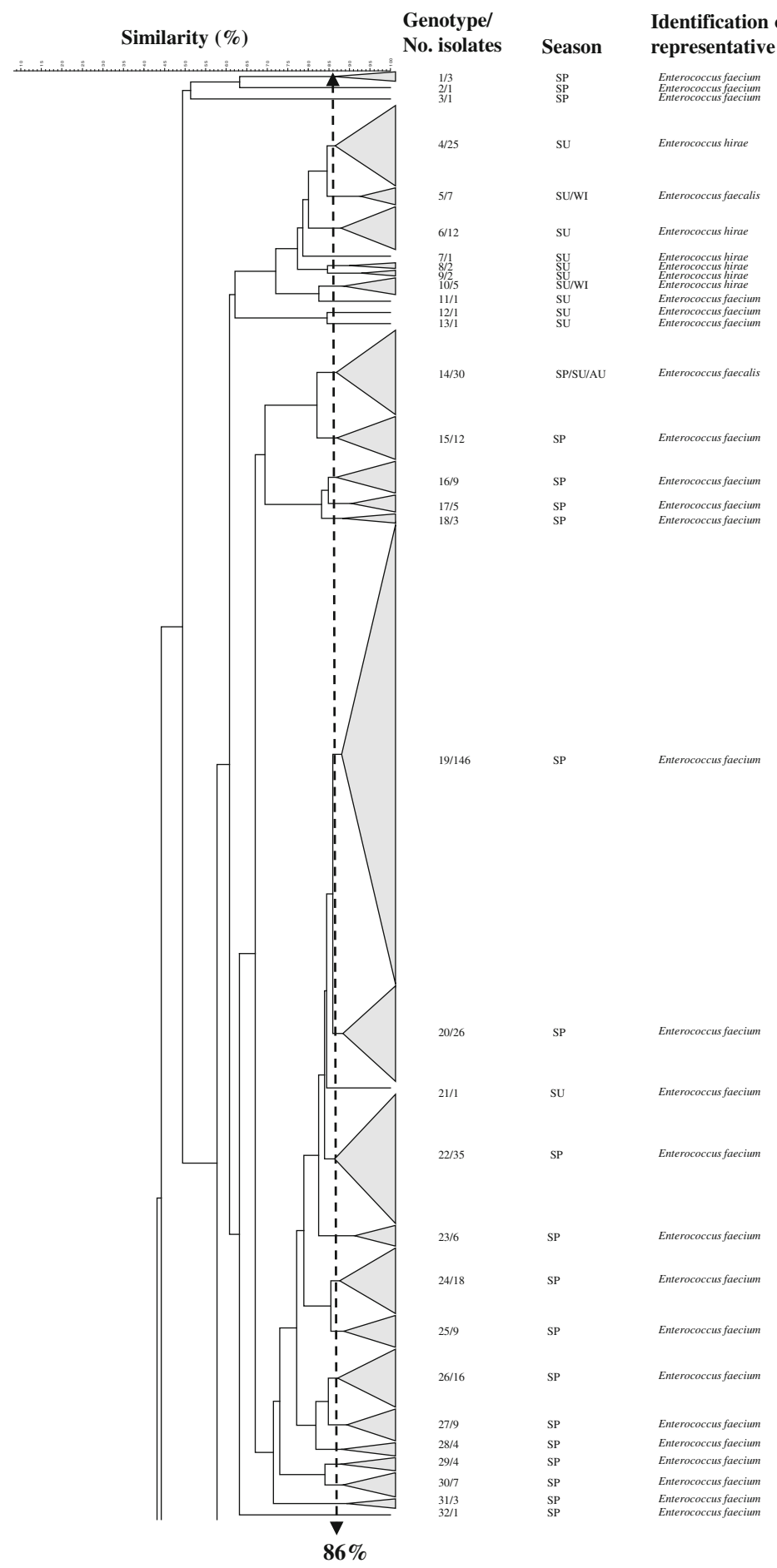

Fig. 1 Abridged dendrogram obtained from UPGMA analysis of RAPD-PCR patterns. The scale indicates the similarity level (Pearson coefficient level $r \times 100$ ). SP, spring; SU, summer; AU, autumn; WI, winter 


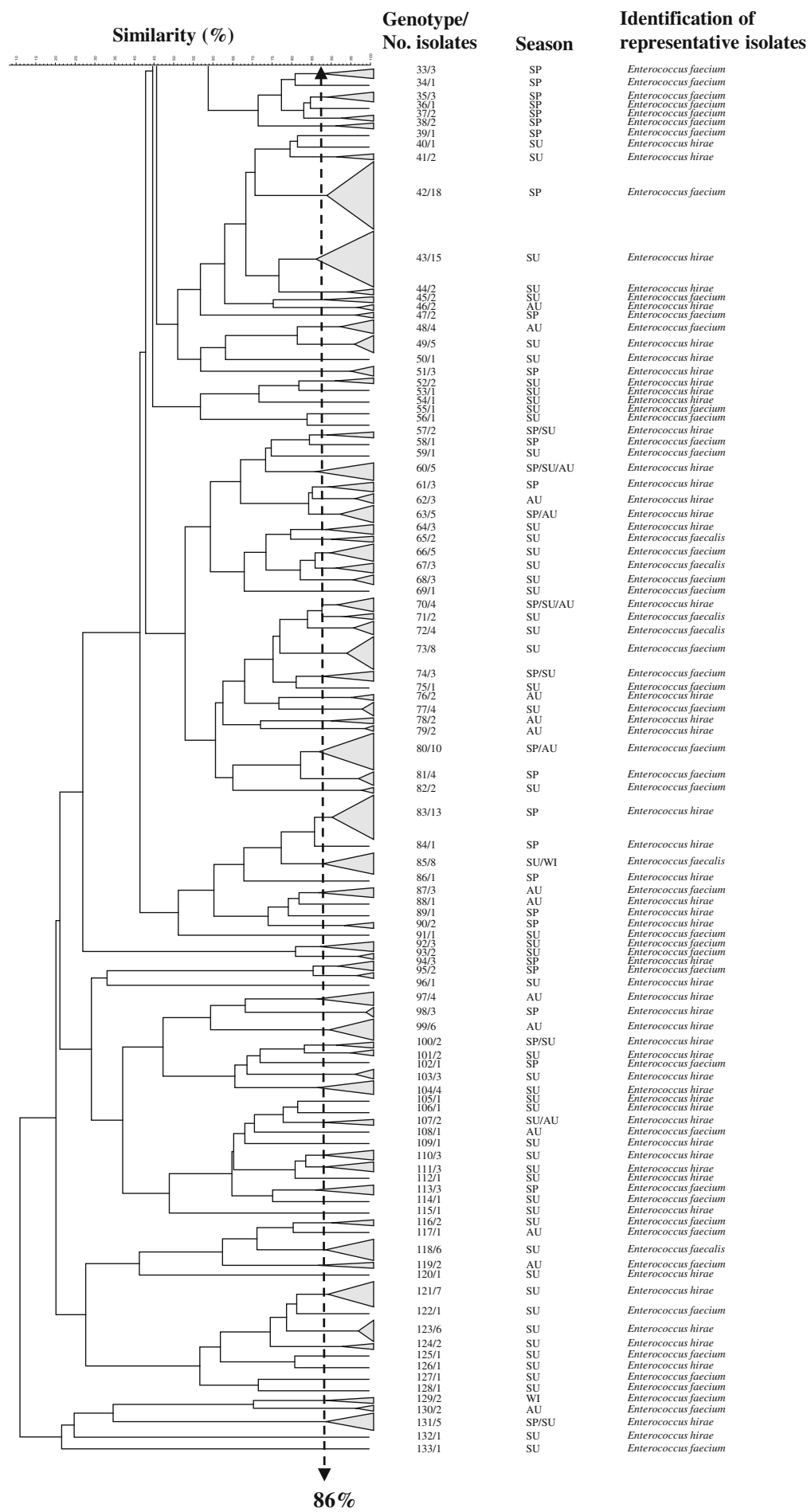

Fig. 1 (continued) 


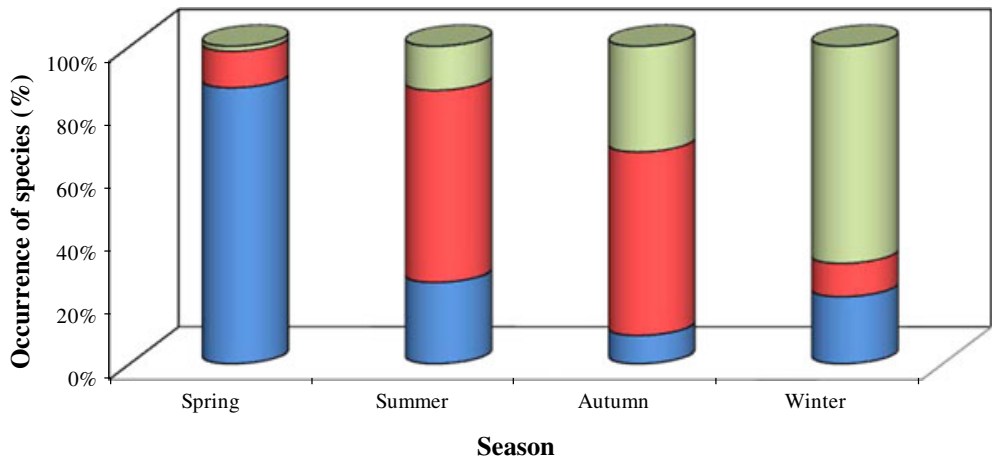

Fig. 2 Percentage of species present at each season. $\square$ E. faecium, $\square$ E. hirae, $\square$ E. faecalis

and tetracycline were similar (64 and 29\%, respectively), but all of them-similar to the winter strains - were susceptible to quinolones, $\beta$-lactams, glycopeptides, chloramphenicol and nitrofurantoin.

Noticeably, the E. faecium and E. hirae strains were resistant to a higher number of antimicrobials than the E. faecalis strains.

PCR analysis for antibiotic resistance genes showed that the tet $\mathrm{M}$ and tet $\mathrm{L}$ genes were more prevalent than the tet $\mathrm{S}$ gene, which was detected in only $11 \%$ of the isolates compared to the $86 \%$ of isolates harbouring tet $\mathrm{M}$ and tet $\mathrm{L}$ (Table 2). Of all the species, $73 \%$ of the strains harboured both tet $\mathrm{M}$ and tet $\mathrm{L}$ genes (data not shown), with 57 of them being from summer samples, 32 from spring samples, seven from autumn samples and one from winter samples. None of the enterococci harboured the gene tet $\mathrm{O}$ that encodes for resistance to tetracycline.

The van $\mathrm{B}$ gene was detected in $51 \%$ of E. faecium strains from spring samples and in an E. hirae strain from a summer sample, while the erm $\mathrm{C}$ gene was detected in $22 \%$ of $E$. hirae strains from autumn samples. van $\mathrm{A}$, van $\mathrm{C} 1$ and $\operatorname{erm} \mathrm{B}$ were not detected in any of the strains.

\subsection{Occurrence of virulence genes}

Multiplex PCR analysis for virulence genes showed a low occurrence of virulence genes in the strains from all seasons: $100 \%$ of winter strains, $95 \%$ of spring strains, $87 \%$ of summer strains, and $67 \%$ of autumn strains did not harbour any of the genes assayed.

The gene found most frequently was the gelE gene, which was present in strains from three seasons, followed by esp and asal genes, which were present in strains from two seasons, and $c y l \mathrm{~A}$, which was only detected in summer strains (Fig. 3). The hyl gene was not detected at any of the strains. The highest diversity of genes was found in strains from autumn and summer samples, with some of them harbouring three out of five of the assayed genes. Only a low percentage $(8.2 \%)$ of summer strains harboured two of these virulence genes simultaneously.

When the results were analysed for each of the species, the highest occurrence of virulence genes was observed for the E. faecalis strains, with $40 \%$ of 


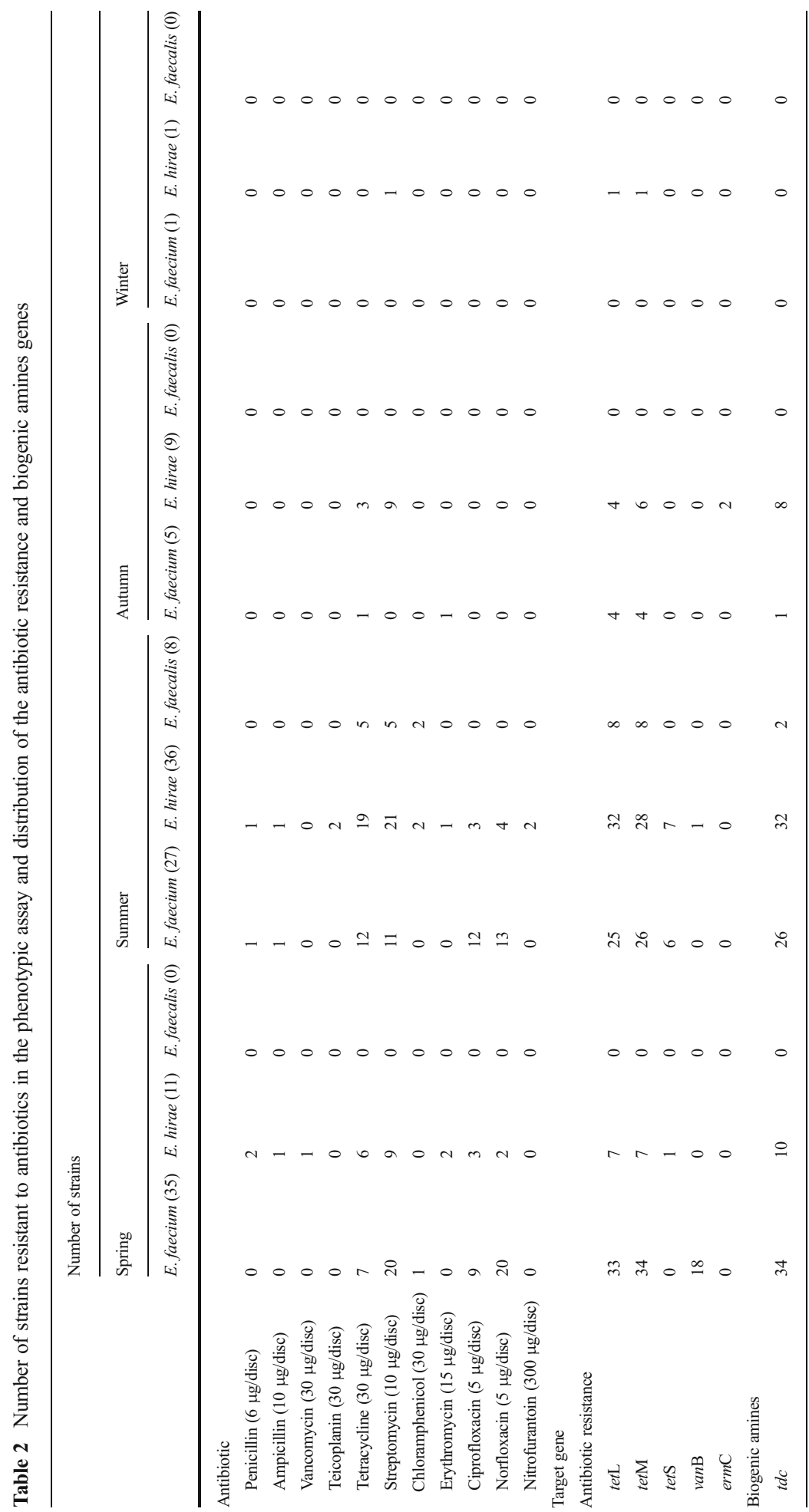




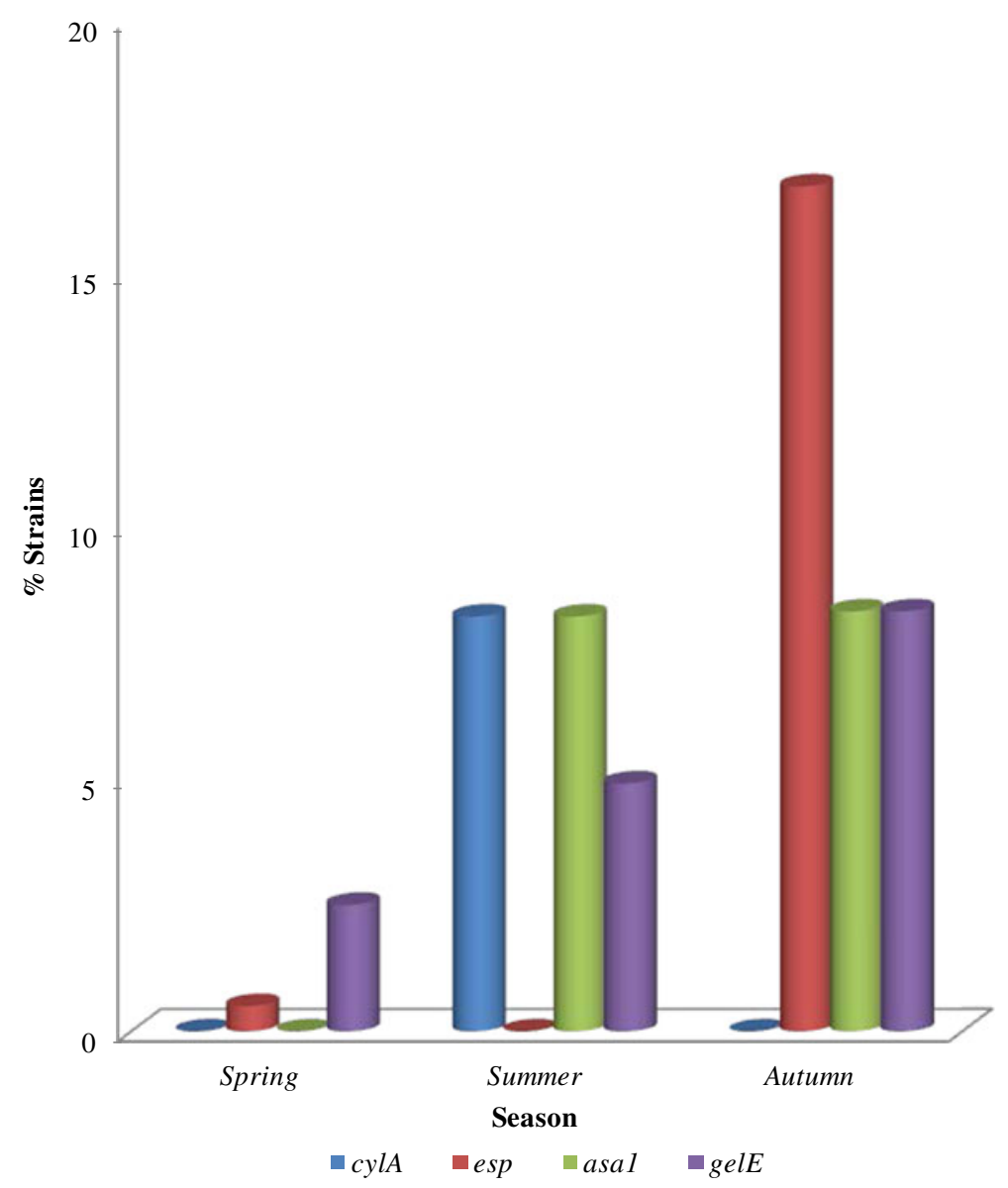

Fig. 3 Percentage of strains of each season harbouring virulence genes

them harbouring two out of five of the assayed genes, and the lowest occurrence was for the E. faecium strains, with only $2.9 \%$ of them harbouring one gene (data not shown).

\subsection{Biogenic amine production}

Assays to examine the aminobiogenic capacity were carried out in liquid and solid medium under aerobic and anaerobic conditions, and the results were identical and showed that while all the strains were able to produce tyramine, none produced histamine or cadaverine. Only one E. hirae strain from a spring sample produced putrescine under both incubation conditions assayed.

Results from multiplex PCR reactions targeting the amino acid decarboxylase genes $t d c$, $h d c$ and $o d c$ showed that $96 \%$ of spring strains, $85 \%$ of summer strains and $64 \%$ of autumn strains harboured the $t d c$ gene, while none harboured the $h d c$ or odc genes (Table 2). Biogenic amines genes were not detected in winter strains. 
High percentages of E. faecium (89\%) and E. hirae (88\%) strains harboured the $t d c$ gene, while only $25 \%$ of the E. faecalis strains harboured $t d c$.

\section{Discussion}

This study evaluated the presence and genetic diversity of enterococci in MurcianoGranadina goat milk samples taken at a farm during four consecutive seasons. In addition, assays to assess some aspects related to their safety were performed.

Counts for enterococci in goat milk samples were similar to those reported by Quigley et al. (2013). The results did not indicate a clear impact of seasons on the counts and only slight differences were observed depending on the time of year. Summer samples showed the highest counts and winter samples the lowest.

Callon et al. (2007), in a study to examine the microbial diversity in goat milk samples taken from one herd throughout one lactation year, revealed differences in microbial counts that were attributed to differences in the feed and weather conditions. As mentioned in the "Material and methods" section, in this study, the feeding regime was slightly different for the warm and cold seasons, but samples were always taken directly from the animal, which could explain why there were no major differences in the counts between seasons.

Compared with the results reported by Cortés et al. (2006) for goat milk, our data showed a greater diversity of Enterococcus species in samples from all seasons, although this diversity was lower than that reported by Jiménez et al. (2013) for milk from other mammals, such as ewes and humans. As in these studies, E. faecalis and E. faecium were the predominant species in this study. Both species are associated with the intestinal microflora of humans and animals and are considered opportunistic pathogens. The occurrence of Enterococcus species widely fluctuated during seasons and while E. faecalis was predominant in cold seasons (autumn and winter), E. faecium was predominant in warm seasons (spring and summer). In addition, a higher number of genotypes was observed in the summer and spring samples, with 71 and 59 genotypes, respectively, while 15 and 6 genotypes were found in autumn and winter samples, respectively. The free access of goats to pasture in warm seasons could be one of the causes explaining these results.

Enterococci, although usually found in the environment and foods, constitute a reservoir of virulence and/or antibiotic resistance genes, which could be transferred to other microorganisms, either in the food matrix or in the gastrointestinal tract (Mathur and Singh 2005). Consequently, it is important to assay these traits, especially in strains from raw substrates, such as milk, that will be used for foods.

Important differences between studies have been found regarding antibiotic resistance of Enterococcus species, which could, in some cases, be related to the origin of the isolates. Our results from phenotypic resistance assays were consistent with those reported for enterococci from dairy products and human samples by Cariolato et al. (2008) who found that E. faecium isolates were resistant to a higher number of antibiotics than E. faecalis isolates. In contrast, Cortés et al. (2006), for enterococci from bulk tank milk samples from dairy goats, reported that the E. faecium strains assayed were susceptible to all the antimicrobials tested, while the E. faecalis strains were resistant or intermediate to at least one antimicrobial. 
To the best of our knowledge, studies to determine the influence of seasons on the incidence of antibiotic resistance genes in enterococci or other bacterial genus have not been reported. From the results of this study, it can be affirmed that strains from warmer seasons (spring, summer and autumn) were resistant to a higher number of antibiotics, while of the winter strains only one was resistant to the antibiotic streptomycin. However, this result should be confirmed by assaying a higher number of winter strains since it could be only a consequence of the low number of isolates from this season that were assayed. In addition, and given that in the safety evaluation only E. faecalis strains from summer samples were used, it would be advisable to analyse a number of strains of this species from the samples of the remaining seasons.

The greatest concordance between results from the phenotypic antibiotic resistance assay and the PCR analysis for antibiotic resistance genes was observed for E. faecalis strains. As reported by Jamet et al. (2012), a complete concordance was obtained for tetracycline and erythromycin in most of the strains of all the species, while discrepancies were observed for vancomycin. While all the E. faecium strains were sensitive or intermediate in the phenotypic assay for this antibiotic, $26 \%$ of them harboured the $v a n \mathrm{~B}$ gene. This value is high if compared with the results for enterococci isolated from other dairy products and human samples, where the presence of $\operatorname{van} \mathrm{A}$ and $\operatorname{van} \mathrm{B}$ resistance genes has been reported to be low or non-existent (Cariolato et al. 2008; Jiménez et al. 2013). Only the study by Ribeiro et al. (2007) has reported results that are similar to those obtained in this study, although for the van A gene, which was detected in $37 \%$ of the dairy enterococci examined even though all of them were susceptible to vancomycin. The presence of silent antibiotic resistance genes, as reported by Morandi et al. (2013) for Leuconostoc isolates, would explain this finding.

The presence in enterococci of genes encoding virulence factors is another important trait, especially considering that genes for aggregation substances, cytolysin and gelatinase may be silent. This makes the genotypic study even more relevant than the phenotypic assay, because otherwise the pathogenic potential of such strains may be well-overlooked (Creti et al. 2004). From the virulence factor genes assayed, the gelatinase gene (gelE) was the most frequently detected and, as described by Valenzuela et al. (2009), it was more common in E. faecalis strains than in E. faecium strains. In addition, in E. faecalis strains, the presence of multiple virulence genes was usual, as described by Jiménez et al. (2013).

The number of strains harbouring some of the antibiotic resistance genes was higher than that of the virulence genes. In contrast, Cariolato et al. (2008), in a study comparing enterococci from dairy and human samples, reported that virulence determinants were common among dairy isolates, with frequencies in some cases equal to or higher than those found in human isolates, while antibiotic resistance was more frequent within human isolates. Other comparative studies (Creti et al. 2004; Eaton and Gasson, 2001) have also reported that medical strains have more virulence determinants than food strains.

Another important safety aspect of enterococci in foods is their ability to produce biogenic amines, since the intoxication by ingestion of food with high levels of such compounds may be of clinical concern (Giraffa 2002). Thus, a qualitative assay to determine production of biogenic amines and the determination of the presence of genes responsible for biogenic amine production were carried out. 
The ability of LAB to decarboxylate amino acids has been described to be dependent on the species, the strain and even the environment (Fernández et al. 2007). However, tyramine production seems to be a widely distributed trait in Enterococcus species (Fernández et al. 2007; Pérez-Martín et al. 2014) and is sometimes the only biogenic amine produced (Bover-Cid and Holzapfel 1999). In addition, some authors (Jiménez et al. 2013) have suggested that tyramine production ability is a species-level characteristic in E. faecalis, E. faecium and E. hirae, a fact that has been proven in this study, since $100 \%$ of strains of all these species were tyramine producers. Putrescine was also produced by one $E$. hirae strain from a spring sample and histamine was not produced by any of the strains assayed, in concordance with other studies (Jiménez et al. 2013; Pérez-Martín et al. 2014; Ribeiro et al. 2013).

On the other hand, and as mentioned for the antibiotic resistance assays, some tyramine producers and the putrescine producer in the qualitative assay did not harbour the corresponding genes. This may be due, as reported by Coton et al. (2010), to the existence of other $o d c$ and $t d c$ genes that would not be recognised by the degenerate primers used in this study.

\section{Conclusions}

The enterococci population in raw goat milk samples taken at a farm in consecutive seasons was composed of the species E. faecium, E. faecalis and E. hirae. High genetic diversity was found for these species with $92.5 \%$ of clusters grouping isolates from samples of only one season. Summer and spring samples showed a higher number of genotypes.

The season seems to only slightly affect the count, but the season does affect the occurrence of species and the presence of virulence determinants, the susceptibility to antibiotics and the presence of genes involved in biogenic amine production. Strains from warmer seasons were resistant to a higher number of antibiotics in the phenotypic assay and harboured a higher number of antibiotic resistance and virulence genes. The feed regime of goats during the warm seasons was the main difference between samples and thus, it could be proposed that feed would be responsible for the differences found in the results between seasons. To the best of our knowledge, this is the first time that a study assessing seasonal diversity and the influence of seasons on the safety of a bacterial population in a raw food, such as milk, has been reported.

Acknowledgments This research has been financed by the Instituto Nacional de Investigación y Tecnología Agraria y Alimentaria (INIA), Acción Estratégica "Conservación de recursos genéticos de interés agroalimentario" del Plan Nacional de Investigación Científica, Desarrollo e Innovación Tecnológica. Ministerio de Ciencia e Innovación. Project number RM 2010-00010-00-00. Patricia Ruiz was contracted by a charge to the same project. F. Pérez-Martín was supported by a grant of the Council of Communities of Castilla-La Mancha (B.O.E. No. 246, 11th October, 2010) cofounding by European Social Fund (FSE 20072013). We thank Dr. E. Sánchez for providing climate information.

Compliance with ethical standards All applicable institutional and/or national guidelines for the care and use of laboratory animals were followed.

Conflict of interest The authors declare that they have no competing of interests. 


\section{References}

Bensalah F, Flores MJ, Mouats A (2006) A rapid PCR based method to distinguish between Enterococcus species by using degenerate and species-specific sodA gene primers. Afr J Biotechnol 5:697-702

Bover-Cid S, Holzapfel WH (1999) Improved screening procedure for biogenic amine production by lactic acid bacteria. Int J Food Microbiol 53:33-41

Callon C, Duthoit F, Delbes C, Ferrand M, Le Frileux Y, De Cremoux R, Montel MC (2007) Stability of microbial communities in goat milk during a lactation year: molecular approaches. Syst Appl Microbiol 30:547-560

Cariolato D, Andrighetto C, Lombardi A (2008) Occurrence of virulence factors and antibiotic resistances in Enterococcus faecalis and Enterococcus faecium collected from dairy and human samples in North Italy. Food Control 19:886-892

Clinical and Laboratory Standards Institute (CLSI) (2012) Performance standards for antimicrobial susceptibility testing: twenty-second informational supplement. CLSI Document M100-S22. Wayne, PA

Comunian R, Daga E, Dupré I, Paba A, Devirgiliis C, Piccioni V, Perozzi G, Zonenschain D, Rebecchi A, Morelli L, De Lorentiis A, Giraffa G (2010) Susceptibility to tetracycline and erythromycin of Lactobacillus paracasei strains isolated from traditional Italian fermented foods. Int J Food Microbiol 138:151-156

Cortés C, De la Fuente R, Contreras A, Sánchez A, Corrales JC, Ruiz-Santa-Quiteria JA, Orden JA (2006) Occurrence and preliminary study of antimicrobial resistance of enterococci isolated from dairy goats in Spain. Int J Food Microbiol 110:100-103

Coton E, Coton M (2005) Multiplex PCR for colony direct detection of Gram-positive histamine- and tyramine-producing bacteria. J Microbiol Methods 63:296-304

Coton M, Coton E, Lucas P, Lonvaud-Funel A (2004) Identification of the gene encoding a putative tyrosine decarboxylase of Carnobacterium divergens 508. Development of molecular tools for the detection of tyramine-producing bacteria. Food Microbiol 21:125-130

Coton M, Romano A, Spano G, Ziegler K, Vetrana C, Desmarais C, Lonvaud-Funel A, Lucas P, Coton E (2010) Occurrence of biogenic amine-forming lactic acid bacteria in wine and cider. Food Microbiol 27: 1078-1085

Creti R, Imperi M, Bertuccini L, Fabretti F, Orefici G, Di Rosa R, Baldassarri L (2004) Survey for virulence determinants among Enterococcus faecalis isolated from different sources. J Med Microbiol 53:13-20

Depardieu F, Perichon B, Courvalin P (2004) Detection of the van alphabet and identification of enterococci and staphylococci at the species level by multiplex PCR. J Clin Microbiol 42:5857-5860

Eaton TJ, Gasson MJ (2001) Molecular screening of Enterococcus virulence determinants and potential for genetic exchange between food and medical isolates. Appl Environ Microbiol 67:1628-1635

Edwards U, Rogall T, Blacker H, Emde M, Bottger EC (1989) Isolation and direct complete nucleotide determination of entire genes. Characterization of a gene coding for 16S ribosomal RNA. Nucleic Acids Res 17:7843-7853

Fernández M, Linares DM, Rodríguez A, Álvarez MA (2007) Factors affecting tyramine production in Enterococcus durans IPLA 655. Appl Microbiol Biotechnol 73:1400-1406

Foschino R, Invernizzi A, Barucco R, Stradiotto K (2002) Microbial composition, including the incidence of pathogens, of goat milk from the Bergamo region of Italy during a lactation year. J Dairy Res 69:213-225

Foulquié Moreno MR, Sarantinopoulos P, Tsakalidou E, De Vuyst L (2006) The role and application of enterococci in food and health. Int J Food Microbiol 106:1-24

Giraffa G (2002) Enterococci from foods. FEMS Microbiol Rev 26:163-171

Jamet E, Akary E, Poisson MA, Chamba JF, Bertrand X, Serror P (2012) Prevalence and characterization of antibiotic resistant Enterococcus faecalis in French cheeses. Food Microbiol 31:191-198

Jiménez E, Ladero V, Chico I, Maldonado-Barragán A, López M, Martín V, Fernández L, Fernández M, Álvarez MA, Torres C, Rodríguez JM (2013) Antibiotic resistance, virulence determinants and production of biogenic amines among enterococci from ovine, feline, canine, porcine and human milk. BMC Microbiol 13:288

Kojima A, Morioka A, Kijima M, Ishihara K, Asai T, Fujisawa T, Tamura Y, Takahashi T (2010) Classification and antimicrobial susceptibilities of Enterococcus species isolated from apparently healthy food-producing animals in Japan. Zoonoses Public Health 57:137-141

Komprda T, Sládková P, Petirová E, Dohnal V, Burdychová R (2010) Tyrosine- and histidine-decarboxylase positive lactic acid bacteria and enterococci in dry fermented sausages. Meat Sci 86:870-877

Lemcke R, Bülteb M (2000) Occurrence of the vancomycin-resistant genes $\operatorname{van} \mathrm{A}, \operatorname{van} \mathrm{B}, \operatorname{van} \mathrm{C} 1, \operatorname{van} \mathrm{C} 2$ and vanC3 in Enterococcus strains isolated from poultry and pork. Int J Food Microbiol 60:185-194 
Martín-Platero AM, Valdivia E, Maqueda M, Martínez-Bueno M (2009) Characterization and safety evaluation of enterococci isolated from Spanish goats' milk cheeses. Int J Food Microbiol 132:24-32

Mathur S, Singh R (2005) Antibiotic resistance in food lactic acid bacteria - a review. Int J Food Microbiol 105:281-295

Morandi S, Cremonesi P, Silvetti T, Brasca M (2013) Technological characterisation, antibiotic susceptibility and antimicrobial activity of wild-type Leuconostoc strains isolated from north Italian traditional cheeses. J Dairy Res 80:457-466

Ng LK, Martin I, Alfa M, Mulvey M (2001) Multiplex PCR for the detection of tetracycline resistant genes. Mol Cell Probes 15:209-215

Nieto-Arribas P, Seseña S, Poveda JM, Chicón R, Cabezas L, Palop ML (2011) Enterococcus populations in artisanal Manchego cheese: biodiversity, technological and safety aspects. Food Microbiol 28:891-899

Nishiyama M, Iguchi A, Suzuki Y (2015) Identification of Enterococcus faecium and Enterococcus faecalis as vanC-type Vancomycin-Resistant Enterococci (VRE) from sewage and river water in the provincial city of Miyazaki, Japan. J Environ Sci Health Part A-Toxic/Hazard Subst Environ Eng 50:16-25

Pérez-Martín F, Seseña S, Izquierdo PM, Palop ML (2014) Are Enterococcus populations present during malolactic fermentation of red wine safe? Food Microbiol 42:95-101

Pérez-Pulido R, Abriouel H, Ben Omar N, Lucas R, Martínez-Cañamero M, Gálvez A (2006) Safety and potential risks of enterococci isolated from traditional fermented capers. Food Chem Toxicol 44:2070-2077

Quigley L, O'Sullivan O, Stanton C, Beresford TP, Ross RP, Fitzgerald GF, Cotter PD (2013) The complex microbiota of raw milk. FEMS Microbiol Rev 37:664-698

Ribeiro T, Abrantes M, Lopes MF, Crespo MT (2007) Vancomycin susceptible dairy and clinical enterococcal isolates carry vanA and vanB genes. Int J Food Microbiol 113:289-295

Ribeiro SC, Coelho MC, Todorov SD, Franco BD, Dapkevicius ML, Silva CC (2013) Technological properties of bacteriocin-producing lactic acid bacteria isolated from Pico cheese an artisanal cow's milk cheese. J Appl Microbiol 116:573-585

Valenzuela AS, Ben Omar N, Abriouel H, Lucas López R, Veljovic K, Martínez Cañamero M, Topisirovic MKL, Gálvez A (2009) Virulence factors, antibiotic resistance, and bacteriocins in enterococci from artisan foods of animal origin. Food Control 20:381-385

Valenzuela AS, Ben Omar N, Abriouel H, Martínez Cañamero M, Gálvez A (2010) Isolation and identification of Enterococcus faecium from seafoods: antimicrobial resistance and production of bacteriocin-like substances. Food Microbiol 27:955-961

Vankerckhoven V, Van Autgaerden T, Vael C, Lammens C, Chapelle S, Rossi R, Jabes D, Goznes H (2004) Development of a multiplex PCR for the detection of asal, gelE, cylA, esp, and hyl genes in enterococci and survey for virulence determinants among European hospital isolates of Enterococcus faecium. J Clin Microbiol 42:4473-4479 